\section{REFERENCES AND NOTES}

1. Ando, T., Rasmussen, K., Wright, J. M., and Nyhan, W. L.: Isolation and identification of methylcitrate, a major metabolic product of propionate in patients with propionic acidemia. J. Biol. Chem., 247: 2200 (1972).

2. Barley, F. W., Sato, G. H., and Abeles, R. H.: An effect of vitamin $B_{12}$ deficiency in tissue culture. J. Biol. Chem., 247: 4270 (1972).

3. Cardinale, G. J., Carty, T. J., and Abeles, R. H.: Effect of methylmalonyl coenzyme $\mathrm{A}$, a metabolite which accumulates in vitamin $\mathrm{B}_{12}$ deficiency on fatty acid synthesis. J. Biol. Chem., 245: 3771 (1970).

4. Chappell, J. B.: Systems used for the transport of substrates into mitochondria. Brit. Med. Bull., 24: 150 (1968).

5. Cheema-Dhadli, S., Halperin, M. L., and Leznoff, C. C.: Inhibition of enzymes which interact with citrate by (-)hydroxycitrate and 1,2,3-tricarboxybenzene. Eur. J. Biochem., 38: 98 (1973).

6. Cheema-Dhadli, S., Halperin, M. L., and Robinson, B. H.: Unpublished observations.

7. Fritz, I. B., Cheema-Dhadli, S., Taylor, W. M., Morris, H. P. and Halperin, M L.: Inhibition of hepatic fatty acid synthesis by long chain acyl CoA derivatives: Role of the mitochondrial citrate transporter. Alfred Benzon Symp., 6: 645 (1974).

8. Fritz, I. B., and Lee, L.: Fat mobilization and ketogenesis. In: D. F. Steiner and N. Freinkel: Handbook of Physiology: Endocrinology, Vol. I, p. 579 (The Williams \& Wilkins Co., Baltimore, 1972).

9. Goodridge, A. G.: Regulation of the activity of acetyl coenzyme A carboxylase by palmitoyl coenzyme A and citrate. J. Biol. Chem., 247:6946 (1972).

10. Habicht, E., and Schneeberger, P.: Synthese einiger substituiester citronensaüren. Helv. Chim. Acta, 39: 1316 (1956).

11. Halperin, M. L.. Cheema-Dhadli, S., Taylor, W. M., and Fritz, I. B. Role of the citrate transporter in the control of fatty acid synthesis. Advan. Enzyme Regul., 13: 435 (1975).

12. Halperin, M. L., Robinson, B. H., and Fritz, I. B.: Effects of palmitoyl CoA on citrate and malate transport by rat liver mitochondria. Proc. Nat. Acad. Sci. U. S. A., 69: 1003 (1972).

13. Halperin, M. L., Schiller, C. M., and Fritz, I. B.: The inhibition by methylmalonic acid of malate transport by the dicarboxylate carrier in rat liver mitochondria. J. Clin. Invest., 50:2276 (1971).

14. Hommer, F. A., Kuipers, J. R. G., Elema, J. D., Jansen, J. T., and Jonxis, J. H. P.: Propionicacidemia, a new inborn error of metabolism. Pediat. Res., 2: 519 (1968).

15. Kishimoto, Y., Williams, M., Moser, H. W. Hignite, C., and Biemann, K. Branched-chain and odd-numbered fatty acids and aldehydes in the nervous system of a patient with deranged vitamin $B_{12}$ metabolism. J. Lipid Res., 14 : 69 (1973).

16. Lowenstein, A., and Roberts, J. D.: The ionization of citric acid studied by the nuclear magnetic resonance technique. J. Amer. Chem. Soc. 82:2705 (1960).

17. Lowenstein, J. M.: Citrate and the conversion of carbohydrate into fat. Biochem. Soc. Symp., 27: 61 (1968).

Copyright (c) 1975 International Pediatric Research Foundation, Inc.
18. Lowry, O. H., Rosebrough, N. J., Farr, A. L., and Randall, R. J.: Protein measurement with the Folin phenol reagent. J. Biol. Chem., 193: 265 (1951).

19. Moellering. H., and Gruber, W.: Determination of citrate with citrate lyase. Anal. Biochem., 17:369 (1966).

20. Numa, S., Bortz, W. M., and Lynen, F.: Regulation of fatty acid synthesis at the acetyl-CoA carboxylase step. Advan. Enzyme Regul., 3: 407 (1967).

21. Oberholzer, V. G., Levin, B., Burgess, E. A., and Young W. F.: Methylmalonic aciduria, an inborn error of metabolism leading to chronic metabolic acidosis. Arch. Dis. Childhood, 42: 492 (1967).

22. Robinson, B. H. Williams, G. R., Halperin, M L and Leznoff, C. C. The effects of 2-ethylcitrate and tricarballylate on citrate transport in rat liver mitochondria and fatty acid synthesis in rat white adipose tissue. Eur. J. Biochem., 15: 263 (1970).

23. Robinson, B. H., Williams, G. R., Halperin, M. L., and Leznoff, C. C: The sensitivity of the exchange reactions of tricarboxylate, 2-oxoglutarate and dicarboxylate transporting systems of rat liver mitochondria to inhibition by 2-pentylmalonate, p-iodobenzylmalonate and benzene 1,2,3-tricarboxylate. Eur. J. Biochem., 20: 65 (1971)

24. Robinson, B. H., Williams, G. R., Halperin, M. L., and Leznoff, C. C.: Factors affecting the kinetics and equilibrium of exchange reactions of the citrate-transporting system of rat liver mitochondria. J. Biol. Chem., 246: 5280 (1972)

25. Schiller, C. M., Taylor, W. M. and Halperin, M. L. Control of fatty acid synthesis in white adipose tissue by insulin: Coordination between mitochondrial citrate transporter and pyruvate dehydrogenase. Can. J. Biochem., 52. 813 (1974).

26. Stern, J. R.: Oxalacetate transacetase (condensing enzyme, citrogenase). In: P. D Boyer, H. Lardy, and K. Myrbäck: The Enzymes, Vol. V, p. 367 (Academic Press, New York, 1961).

27. Taylor, W. M., and Halperin, M. L.: Regulation of pyruvate dehydrogenase in muscle: Inhibition by citrate. J. Biol. Chem., 248: 6080 (1973).

28. High Oak Ranch, Goodwood, Ontario.

29. New York, N. Y.

30. St. Louis, Mo.

31. Plainview, N. Y.

32. Don Mills, Ontario.

33. The authors are very grateful for the expert technical assistance of Ms. Barbara Green and Ms. Marina Leung and to Drs. I. B. Fritz, Brian Robinson, Frances Rolleston, and Wayne Taylor for helpful advice and discussions.

34. Dr. M. L. Halperin is recipient of Grant MT 3363 from the Medical Research Council of Canada.

35. This research was supported in part by St. Micheal's Research Society and the Banting Research Foundation.

36. Requests for reprints should be addressed to: S. Cheema-Dhadli, Ph.D., Rm. 7363. Medical Sciences Bldg., University of Toronto, Toronto, Ontario M5S IA8 (Canada).

37. Accepted for publication July 25, 1975
Brain fibroblasts liver

\title{
Sphingomyelinases in Human Tissues. II. Absence of a Specific Enzyme from Liver and Brain of Niemann-Pick Disease, Type $\mathrm{C}$
}

\author{
J. W. CALLAHAN ${ }^{(31)}$ AND M. KHALIL \\ Research Institute, Hospital for Sick Children, Toronto Ontario, Canada
}

M. PHILIPPART

Neuropsychiatric Institute, UCLA, Los Angeles, California, USA

Extract

Sphingomyelinase was obtained in excellent yield from liver and brain by homogenization with $0.05 \mathrm{M}$ citrate-phosphate buffer, $\mathrm{pH}$
4.5, containing $0.25 \%$ Triton $X-100(v / v)$ followed by dialysis of the supernatant fluids against $1 \%$ glycine. Total recovery of enzyme was slightly less with tissue from Niemann-Pick disease compared with control tissue. 
Isoelectric focusing of liver and brain extracts was successfully used to resolve several species of sphingomyelinase. Three (I-III) of the five species were partially characterized. Enzyme I (pI 4.6) had a $\mathrm{pH}$ optimum of 4.8-5.0 in acetate buffer and a $\mathrm{K}_{\mathrm{m}}$ value of $0.026 \mathrm{mM}$. Both sphingomyelinases I and II were the major enzymes, whereas III, IV, and V were found at lower levels. Of the two major species in normal liver and brain ( $\mathrm{I}$ and II), species I alone persisted in liver from the two cases of type $C$, while species III, IV, and V were present. In brain, only species II was decreased but the resolution of the brain enzymes was less satisfactory.

\section{Speculation}

Sphingomyelinases exist in multiple molecular forms in human liver and brain. In Niemann-Pick disease, type C, a deficiency of a specific sphingomyelinase was noted in liver and brain from two patients. The lack of this enzyme probably reflects the genetic defect in this disease.

Niemann-Pick disease exists as several distinct clinical and biochemical entities, all of which are characterized by the accumulation of sphingomyelin in the major visceral organs. All types of Niemann-Pick disease differ, however, with respect to degree of sphingomyelin storage in the viscera and nervous system, age of onset and death, and severity of neurologic abnormalities (7). Although sphingomyelin storage bears a primary relationship to the genetic defects in these diseases, the reasons for storage of other lipids such as cholesterol, bis(monoacylglyceryl) phosphate, and several glycolipids in a variety of tissues are poorly understood $(13,14,17,18)$. Sphingomyelinase (sphingomyelin phosphodiesterase, EC. 3.1.4.12) is virtually absent in type A, is reduced to about $10 \%$ of normal in liver and spleen of type B patients and is near normal in most tissues in type $C(2,20,21)$.

The variability of clinical and biochemical expression led us to the view that multiple species of sphingomyelinase must exist in human tissues and that defects in one or more of these forms probably underlined the various types of this disease. Lowden and La Ramee (10) suggested previously the presence of at least two species of sphingomyelinase in human liver.

A recent report from this laboratory has demonstrated the presence of at least two major species of sphingomyelinase in human liver, one of which was absent from the liver of a patient with Niemann-Pick disease, type C (5). In this report, we wish to present additional data on the liver enzymes and extend our observations to the brain of two additional cases of type C. A preliminary report of this work has appeared (6).

\section{MATERIALS AND METHODS}

\section{CASE MATERIAL}

Autopsy specimens of liver and brain were obtained within $24 \mathrm{hr}$ of death and stored at $-20^{\circ}$ in closed containers until used. Liver and brain from two cases of type C Niemann-Pick disease were also analyzed. Case I (TA) had markedly delayed milestones, she was deaf, and developed cerebellar ataxia before death at 7 years of age. She was found to have hepatosplenomegaly in infancy. Numerous foam cells were observed in the bone marrow but there were no sea-blue histiocytes. $G_{M_{2}}$ and $G_{M 3}$ gangliosides were increased in the cortex and the white matter. Sphingomyelin content of the liver and spleen was 3.4 and $9.3 \mathrm{mg} / \mathrm{g}$ wet weight compared with normal values of 1.1 and $2.5 \mathrm{mg} / \mathrm{g}$ wet weight, respectively. The sphingomyelin content of brain gray and white matter was normal. Case $2(F M)$ died at the age of 5 and details on this patient have been presented (17). Data on the neutral and acidic glycolipid levels in liver and spleen from both patients have been reported elsewhere (16).

\section{CHEMICALS}

Bovine brain sphingomyelin, synthetic substrates (nitrophenyl$\beta$-galactopyranoside and $\mathrm{N}$-acetyl- $\beta$-D-glucosaminide), and crystalline bovine serum albumin were purchased from Sigma Chemical Co. (24). Reagent grade sucrose was purchased from Fisher Scientific (25), and the carrier ampholines were a product of LKB Instruments (26).

\section{TISSUE EXTRACTION}

The procedure used for preparation of the tissue extracts was the same as reported earlier (5). In general, $1 \mathrm{~g}$ liver and $2 \mathrm{~g}$ brain tissue were used per experiment. Tissues were minced with scissors and homogenized in 10 volumes cold $0.05 \mathrm{M}$ citrate-phosphate (Mc Ilvaine) buffer, $\mathrm{pH} 4.5$, containing $0.25 \%$ (v/v) Triton X-100 in a Sorvall Omnimixer ( $30 \mathrm{sec}$, top speed). After $5 \mathrm{~min}$ in an ice bath the extraction was repeated. The extract was centrifuged in a Beckman J-21 centrifuge at $2^{\circ}$ for $30 \mathrm{~min}$ at $31,500 \times g$, average speed. The pellet was re-extracted as above. The supernatant fluids were dialyzed in separate sacs against 2 liters of $1 \%$ glycine for 20 hr at $2^{\circ}$. At the end of this period, the dialyzed sac contents were centrifuged as above.

\section{ISOELECTRIC FOCUSING}

Isoelectric focusing was carried out on the combined supernatant fluids in a Uniphor 7900 column electrophoresis system (27). The enzyme extract containing 40-50 mg and 20-26 mg protein for liver and brain, respectively, was exposed to current for $40-44 \mathrm{hr}$ at a maximum voltage of $600 \mathrm{~V}$ in the presence of a sucrose gradient and $3 \%$ carrier ampholines, $\mathrm{pH}$ range $4-7$. The temperature was thermostatically maintained at $3.0-4.0^{\circ}$. The column was eluted from below at a flow rate of $1 \mathrm{ml} / \mathrm{min}$ and $0.8-1.0-\mathrm{ml}$ fractions (25 drops/tube) were collected. Enzyme activities were measured in the presence of ampholines and sucrose. The $\mathrm{pH}$ of the fractions was measured with a combination microelectrode in an ice bath.

\section{ENZYME ASSAYS}

Tritium-labeled sphingomyelin was purified as described previously (5). Sphingomyelinase was measured according to the method of Schneider and Kennedy (20). The assay mixture contained, in a final volume of $0.2 \mathrm{ml}: 25 \mu \mathrm{mol}$ acetate buffer, $\mathrm{pH}$ $5.0 ; 33.3 \mathrm{nmol}\left[{ }^{3} \mathrm{H}\right]$ sphingomyelin $(50,000 \mathrm{cpm}) ; 0.2 \mathrm{mg}$ Triton $\mathrm{X}-100$; water; and 10-20 $\mu 1$ eluate. Incubations were carried out for $1 \mathrm{hr}$ at $37^{\circ}$. The $\left[{ }^{3} \mathrm{H}\right]$ ceramide formed was counted in a liquid scintillation counter and the counting efficiency was $48 \%$.

$\beta$-Glucosaminidase was assayed in a final volume of $0.2 \mathrm{ml}$ containing $100 \mathrm{mM}$ citrate-phosphate (Mc Ilvaine) buffer, $\mathrm{pH} 4.4$, $1.25 \mathrm{mM} p$-nitrophenyl- $N$-acetyl- $\beta$-glucosaminide, water, and 10 $\mu 1$ column eluate. Incubation was $30 \mathrm{~min}$ at $37^{\circ}$. Nitrophenyl $\beta$ galactosidase was assayed in a final volume of $0.2 \mathrm{ml}$ containing $100 \mathrm{mM}$ acetate, $\mathrm{pH} 4.0,1.25 \mathrm{mM} p$-nitrophenyl $\beta$-galactopyranoside, water and $50-100 \mu 1$ column eluate. Incubation was for $2 \mathrm{hr}$ at $37^{\circ}$. The reactions were terminated by the addition of

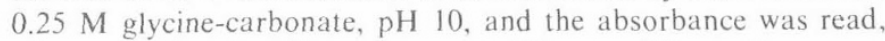
after centrifugation if necessary, at $400 \mathrm{~nm}$. All reactions were linear with time and with protein concentration except as indicated under Results. One unit of activity is the nanomoles of nitrophenol released or sphingomyelin hydrolyzed per hr at $37^{\circ}$. Specific activity is units per mg protein. Protein was determined by the method of Lowry et al. (12) with crystalline bovine serum albumin as standard.

\section{RESULTS}

\section{INITIAL STUDIES}

Sphingomyelinase and two other acid hydrolases, $\beta$-hexosaminidase and $\beta$-galactosidase, were measured in several control specimens and the two cases of type $C$ (Table 1). The three enzymes appear to be stable for several years when the tissue is stored in the frozen state, in agreement with other workers $(2,20)$. Total sphingomyelinase in brain and liver of type $\mathrm{C}$ was generally within the range of the controls. There does not seem to be any age dependence of the liver or brain sphingomyelinase levels. 
The double extraction procedure employed brought at least $90 \%$ of the sphingomyelinase activity into solution in the control samples and at least $86 \%$ of the total in the type C tissues. Only the activities in the initial extraction are shown (Table 2). In general, of the total enzyme recovered, about $85-90 \%$ was obtained in the first supernatant with the remainder recovered on rehomogenization of the residue. Over $90 \%$ of the $\beta$-hexosaminidase and $\beta$-galactosidase was also solubilized by this technique, in agreement with the data of Sandhoff et al. (19). A nonenzymatic protein precipitate which formed on dialysis of the supernatant fluids

Table 1. Sphingomyelinase (SMase) and acid hydrolases in liver and brain $^{1}$

\begin{tabular}{|c|c|c|c|c|}
\hline \multirow[b]{2}{*}{ Diagnosis } & \multirow{2}{*}{$\begin{array}{c}\text { Period } \\
\text { stored, } \\
y \mathrm{yr}\end{array}$} & \multicolumn{3}{|c|}{ Specific activities $^{2}$} \\
\hline & & SMase & $\beta$-Hex & $\beta$-Gal \\
\hline \multicolumn{5}{|l|}{ Liver } \\
\hline \multirow[t]{7}{*}{ Control } & $<1$ & 7.7 & 1,847 & 78 \\
\hline & 2 & 11.9 & 3,258 & 103 \\
\hline & 4 & 5.5 & 2,015 & 81 \\
\hline & 5 & 7.7 & 6,101 & 160 \\
\hline & 6 & 14.4 & 1,800 & 47 \\
\hline & 6 & 21.0 & 5,051 & 25 \\
\hline & 7 & 15.9 & 6,918 & 153 \\
\hline \multicolumn{5}{|c|}{ Niemann-Pick, C } \\
\hline Case I & 4 & 5.5 & 5,724 & 76 \\
\hline Case 2 & 5 & 11.3 & 7,035 & 172 \\
\hline \multicolumn{5}{|l|}{ Brain } \\
\hline \multirow[t]{3}{*}{ Control } & 1.5 & 28.0 & 1,616 & 32 \\
\hline & 2 & 35.4 & 1,563 & 86 \\
\hline & 4 & 33.2 & 4,213 & 64 \\
\hline \multicolumn{5}{|c|}{ Niemann-Pick, C } \\
\hline Case I & 4 & 43.5 & 3,148 & 39 \\
\hline Case 2 & 5 & 12.8 & 2,942 & 41 \\
\hline
\end{tabular}

${ }^{1}$ Liver ( $\left.1 \mathrm{~g}\right)$ and brain $(2 \mathrm{~g})$ from normal and diseased patients were homogenized in buffer as described. The supernatant fluids were used as enzyme source. All numbers are averages of measurements taken at five protein concentrations. $\beta$-Hex: $\beta$-hexosaminidase; $\beta$-Gal: $\beta$-galactosidase.

${ }^{2}$ Nanomoles of sphingomyelin hydrolyzed or nitrophenol released per hr per mg protein. against $1 \%$ glycine was removed by centrifugation. There was little loss of sphingomyelinase by this method and a noticeable improvement in the linearity of the reaction (Fig. 1). In the crude homogenate, sphingomyelinase activity deviated from linearity at protein concentrations above $100 \mu \mathrm{g}$ in the normal and diseased tissues. After centrifugation and dialysis linearity was improved, although the improvement was less striking in the type $C$ liver. The same observations were made with brain extracts prepared in the same manner. After dialysis against glycine, the specific activity was about 6-fold higher than in the crude extract from normal subjects but only 3 -fold increased in the type $\mathrm{C}$ liver. The net

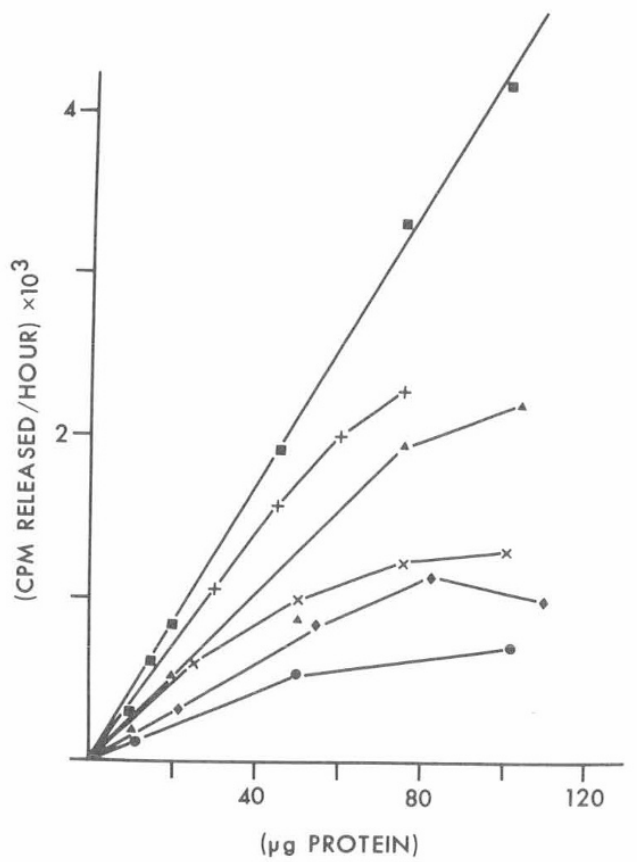

Fig. 1. Effect of protein concentration on linearity of the reaction. Sphingomyelinase activity in extracts of liver from normal tissue and Niemann-Pick, type C (case l) was compared. Fractions from the normal and case $l$ were, respectively: the crude extract ( supernatant fluid after the first extraction $(\mathbf{\Delta}, \times-\times)$, and the glycine-dialyzed supernatant fluids $(\mathbf{-},+-+$ )

Table 2. Extraction of Sphingomyelinase from liver and brain ${ }^{1}$

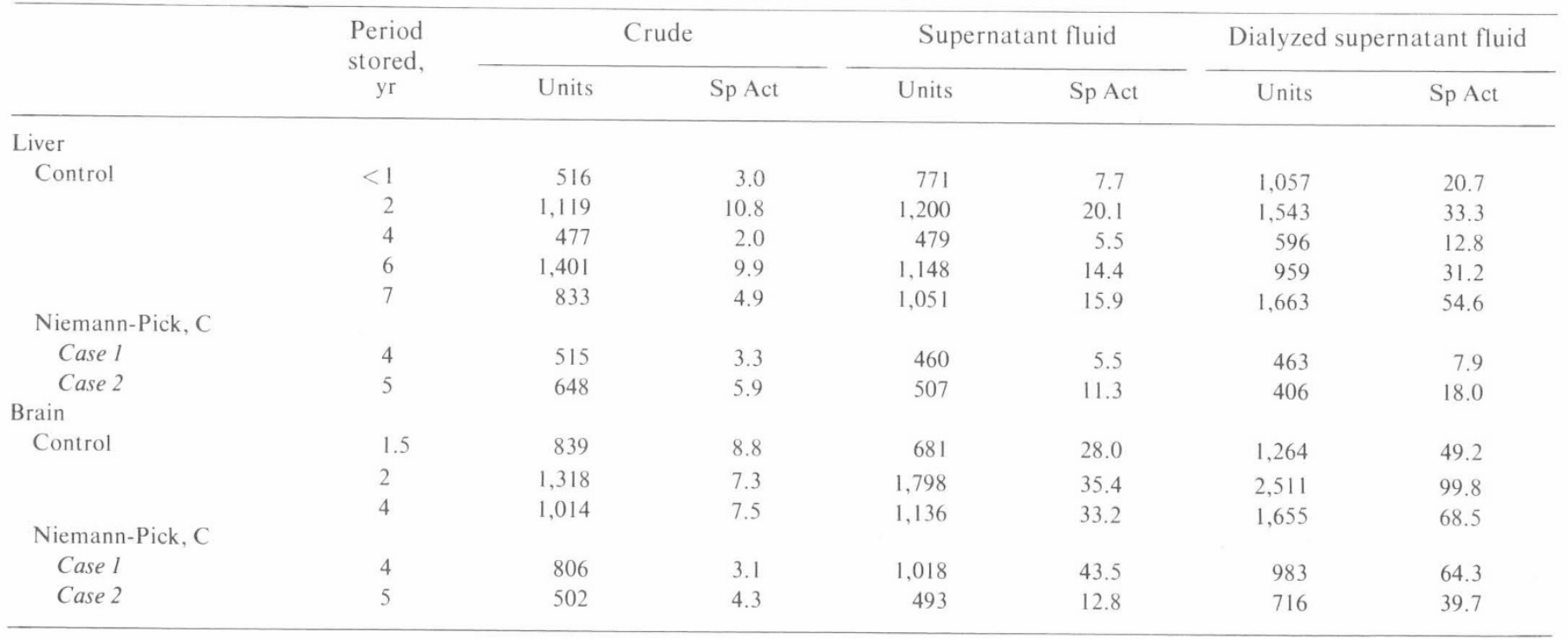

${ }^{1}$ Liver ( $\left.1 \mathrm{~g}\right)$ and brain $(2 \mathrm{~g})$ were homogenized as described. Aliquots of the final dialyzed supernatant fluids were pooled and subjected to electrofocusing. Sp Act: specific activity. 
increase in specific activity in control and type $\mathrm{C}$ brain extracts was 9.5- and 15-fold, respectively.

Equal aliquots of supernatant fluids and the dialyzed extracts prepared from control and type C liver and brain were mixed and sphingomyelinase was determined. There was no difference from the expected values. These results are in agreement with those of other workers (20).

\section{IDENTIFICATION OF SPHINGOMYELINASES IN NORMAL AND NIEMANN-PICK TYPE C LIVER AND BRAIN}

Several species of sphingomyelinase have been identified in human liver (Fig. 2). The major peaks of activity (enzymes I and II) were found at pI 4.7 and 4.9 , respectively, in agreement with previous work $(5,6)$. An additional peak was found at pI 5.1 and this species has been designated enzyme III. Minor amounts of enzyme were located at pl 5.8 and near the top of the gradient (near pI 7.1). These are designated sphingomyelinases IV and V, respectively. Under the experimental conditions employed, $\beta$ hexosaminidases $\mathrm{A}$ and $\mathrm{B}$ have isoelectric points at 4.9 and 7.1 7.4 , respectively, whereas the majority of the $\beta$-galactosidase has an isoelectric point of 4.3-4.7. Recovery of sphingomyelinase and $\beta$-hexosaminidase activities was $90-95 \%$. Dialysis overnight against $1 \%$ glycine reduced $\beta$-galactosidase activity to a very low level before electrofocusing, and recoveries were poor.

We have shown previously in refocusing experiments that sphingomyelinases I, II, and III possess distinct isoelectric points and $\mathrm{pH}$ optima (5). These species differ slightly in their apparent $\mathrm{K}_{m}$ values at the $\mathrm{pH}$ optimum (Table 3). Enzyme I was found to have a $\mathrm{K}_{\mathrm{m}}$ of $0.026 \mathrm{mM}$ in three different control livers at $\mathrm{pH} 5.0$, whereas both II and III have a $\mathrm{K}_{\mathrm{m}}$ value of 0.014 at $\mathrm{pH} 4.0$. Neither species IV nor $\mathrm{V}$ has been studied to date.

Both liver and brain of Niemann-Pick disease type $\mathrm{C}$ have been analyzed (Figs. 2 and 3). In the liver of case 2, enzyme I (pI 4.7) was prominent and species II was substantially reduced (Fig. 2). Species III and IV were also low in the liver of this patient. Species I was also the most prominent species in liver of case I. Again, II and III were lower than normal. In both cases, enzyme $V$ persisted. In control experiments there was no difference in the distribution of sphingomyelinases obtained from the first tissue homogenization compared with that obtained upon re-extraction of the tissue. In addition, there was no difference in species I and II in both control liver and liver from type $\mathrm{C}$ between extracts run before and after dialysis against $1 \%$ glycine. This rules out selective loss of specific enzymes due to the extraction procedures employed. Sphingomyelinase I isolated from the liver of case 2 has the same

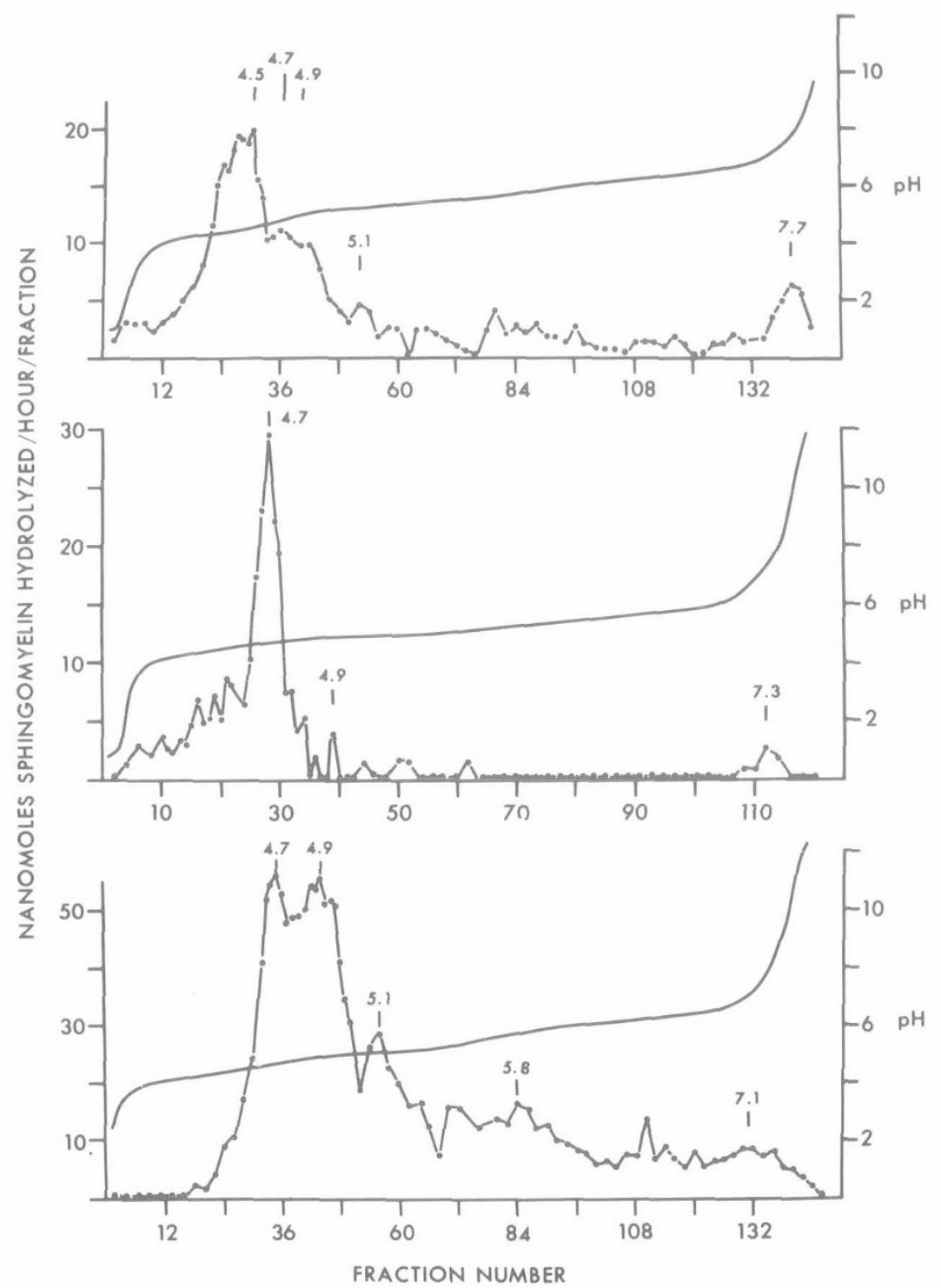

Fig. 2. Sphingomyelinase isoenzymes in normal liver and in Niemann-Pick, type C. The extracts were prepared from $1 \mathrm{~g}$ frozen liver and analyzed separately. Normal liver (lower panel) is compared with liver from case I (upper panel) and from case 2 (middle panel). The isoelectric points of the major peaks are indicated. Recovery was 85,65 , and $78 \%$ for the normal, cases $I$ and 2 , respectively. The pH gradient is the solid line. 
Table 3. Properties of human liver sphingomyelinase isoenzyme

\begin{tabular}{lcclc}
\hline & & & \multicolumn{2}{c}{$\mathrm{K}_{\mathrm{m}}{ }^{1}$} \\
\cline { 4 - 5 } \multicolumn{1}{l}{ Isoenzyme } & $\mathrm{pI}$ & $\mathrm{pH}$ optimum & $\mathrm{pH} 4.0$ & $\mathrm{pH} 5.0$ \\
\hline $\begin{array}{l}\text { Normal } \\
\text { I }\end{array}$ & 4.6 & $4.8-5.0$ & $0.034(2)$ & $0.026(3)$ \\
II & 5.0 & $4.0-4.2$ & $0.014(2)$ & $\begin{array}{c}0.018(3) \\
\text { III }\end{array}$ \\
Niemann-Pick, C \\
I
\end{tabular}

${ }^{1} \mathrm{~K}_{\mathrm{m}}$ values were determined from Lineweaver-Burk plots. A substrate concentration range of $5-263 \mu \mathrm{M}$ was used. The numbers in parentheses indicate the number of separate liver specimens analyzed and the range of values.
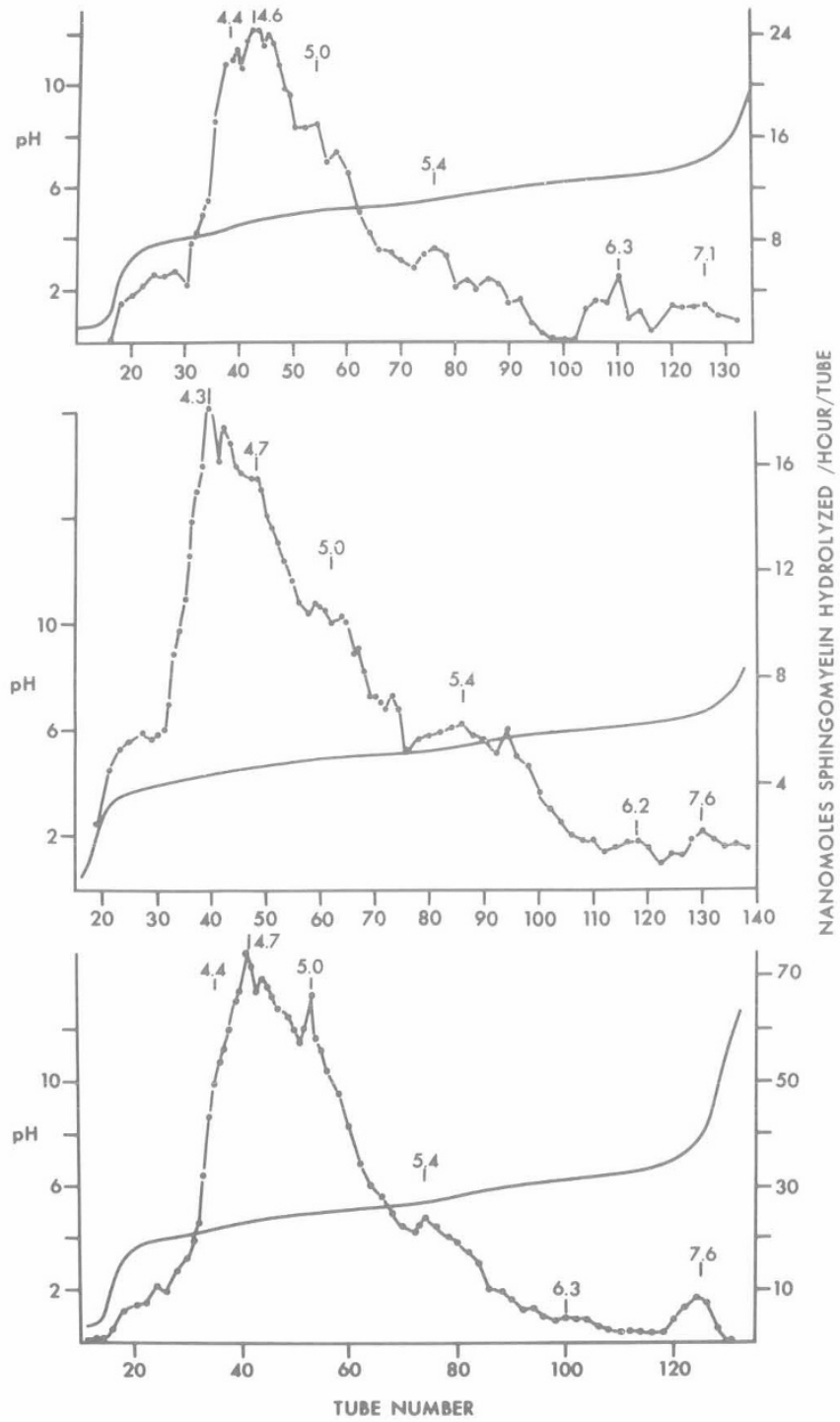

Fig. 3. Sphingomyelinase isoenzymes in human brain. Brain samples ( 2 g) from normal (lower panel), case 1 (upper panel) and case 2 (middle panel) were analyzed. Two major peaks of activity (pI 4.5 and 4.9 ) were found in the normal but were incompletely resolved. In the diseased brain, only the first major peak ( $\mathrm{pI} 4.5$ ) was prominent. Recovery of activity in all instances was over $90 \%$. The solid line represents the $\mathrm{pH}$ gradient.
$\mathrm{pH}$ optimum and $\mathrm{K}_{\mathrm{m}}$ value as isoenzyme I of normal liver (Table $3)$.

In the brain, multiple peaks of sphingomyelinase activity were also seen although the resolution obtained was not as good as in liver. Sphingomyelinase I, with a pI of $4.5-4.7$, was the most prominent species discerned. A small peak was seen in all of the brain samples tested at pI values between 3.6 and 4.1. In the type $\mathrm{C}$ brain samples, there was peaking at pI values between 4.3 and 4.7, whereas in the control presented, a single peak at a pI of 4.7 is shown. In the control (Fig. 3), additional peaks of activity are present at pI 5.0 and at pI 5.4, at pI 6.0 and at pI 7.6. The latter three enzymes have been designated III, IV, and V, respectively, and probably correspond to the same enzymes seen in liver. The peak at pI 5.0 (sphingomyelinase II) was reduced in both brain specimens from type C. Although the loss of this enzyme is less striking than in liver, it nevertheless does suggest that a specific deficiency of sphingomyelinase II exists in brain as in liver in Niemann-Pick disease type C.

\section{DISCUSSION}

Normal liver and brain contain several species of sphingomyelinase on the basis of isoelectric focusing experiments. The liver enzymes have distinct isoelectric points and $\mathrm{pH}$ optima but similar $\mathrm{K}_{\mathrm{m}}$ values. Both liver and brain from two cases of Niemann-Pick disease type $\mathrm{C}$ contain enzyme $\mathrm{I}$, which possesses the same properties as enzyme I in normal tissues. In liver of type C, there is a specific decrease in sphingomyelinase activity associated with species II. The resolution of the brain sphingomyelinases was less satisfactory than for liver and little is known about the separated brain enzymes. The data do suggest, however, that a specific reduction in activity associated with enzyme II exists in the brains of these patients. The data presented here confirm our initial observation $(5,6)$ of a specific decrease in sphingomyelinase activity in type $\mathrm{C}$ patients. On this basis, the genetic defect in Niemann-Pick disease type $C$ has been recognized.

In a previous communication (5) it was thought that species II and III were the same enzyme because of similar pH optimum and $\mathrm{K}_{\mathrm{m}}$ values; species III was called IIb. Since this nomenclature was confusing, we have reverted to the present usage.

The various species of sphingomyelinase have not been well characterized and little is known about the structural relationships between the species recognized to date. In preliminary experiments extracts from normal and type $\mathrm{C}$ liver were prepared separately and mixed before electrofocusing or were homogenized together and then focused. In both instances, species I was higher than II, whereas III, IV, and V were unchanged. This suggests that each species is a separate and distinct enzyme.

We have recently analyzed a specimen of liver from a case of Niemann-Pick disease type-B (4). Sphingomyelinases I-IV were present but were reduced to barely detectable levels. Only species $\mathrm{V}$ persisted at or near the normal level. Although preliminary, these data do suggest that sphingomyelinases I - IV may be related structurally. This observation has been confirmed in cultured fibroblasts derived from another patient with type B (3). It remains unclear whether the various species of sphingomyelinase recognized in this work can be called isoenzymes and we have attempted to avoid this usage.

Several authors have noted that sphingomyelin storage is moderate in liver and spleen in type $\mathrm{C}$ when compared with the massive deposition found in these organs in types A and B (7, 14, 20). Sphingomyelin is the only known substrate for all species of sphingomyelinase in all tissues, and in Niemann-Pick disease type $\mathrm{C}$, sphingomyelin storage occurs in certain tissues in the presence of normal or elevated amounts of one major enzyme species which hydrolyzes the lipid in vitro. To reconcile this dilemma we must assume that all species of sphingomyelinase are required for normal catabolism of this lipid in vivo. The absence of sphingomyelinase II may be sufficiently severe to upset the metabolic 
alance such that catabolic demand outweighs the capacity for reakdown. In the liver, this leads to accumulation of sphinomyelin at a moderate rate presumably due to the active role of he liver and other lymphoid tissues such as spleen in endocytosis 15).

Also, no accumulation of sphingomyelin has been demonstrated n the brains of patients with type $\mathrm{C}$. The neurons in these patients re clearly abnormal and the accumulation of several glycolipids, otably the monosialongangliosides, has been well documented ( 14 . 7). Kamoshita et al. (8) have shown recently that myelin isolated rom a patient with the type $\mathrm{A}$ form had a normal sphingomyelin ontent in spite of overt storage in other cells of white matter, whereas membranous cytosomes isolated from gray matter of the ame patient contained a high proportion of sphingomyelin. It thus eems possible that brain contains additional sphingomyelinases of he type described briefly by Schneider and Kennedy (20), which nay be largely inactive in the present assay system.

Sphingomyelinase is principally but not exclusively a lysosomal snzyme $(1,9,20,22)$. Specific enrichment of sphingomyelin in rriton-loaded lysosomes has been demonstrated in rat liver (23). Unfortuantely, no data on the distribution of sphingomyelinase were presented in the latter study. It is possible that storage of sphingomyelin leads to formation of residual bodies and to a loss of several lysosomal hydrolases, including sphingomyelinase, thus decreasing net hydrolysis of membrane components. Lowden and La Ramee $(10,11)$ have found that sphingomyelinase in liver from a patient with type $\mathrm{C}$ was largely soluble compared with frozen normal liver controls in which only $40 \%$ of the enzyme was soluble.

Complete explanation of the apparent discrepancy between sphingomyelin storage in type $\mathrm{C}$ and the presence of ample amounts of one major species which hydrolyzes the lipid in vitro cannot be made at the present time. It is hoped that further work on subcellular fractionation and characterization of the multiple forms of sphingomyelinase will elucidate these questions.

\section{SUMMARY}

Sphingomyelinase can be resolved into at least five species by isoelectric focusing of human tissues. Each enzyme has a characteristic isoelectric point but all those tested have similar $\mathrm{K}_{\mathrm{m}}$ values. Of the two major species in liver and brain, a specific deficiency of sphingomyelinase II was detected in liver and brain from two patients afflicted with Niemann-Pick disease, type C.

\section{REFERENCES AND NOTES}

1. Barnholz, Y., Roitman, A.. and Gatt. S.: Enzymatic hydrolysis of sphingolipids: Hydrolysis of sphingomyelin by an enzyme from rat brain. J. Biol. Chem., 24I: 3731 (1966).

2. Brady, R. O. Kanfer, J, N. Mock, M B., and Fredrickson, D S. The metabolism of sphingomvelin. II. Evidence of an enzymatic deficiency in Niemann-Pick disease. Proc. Nat. Acad. Sci. U. S. A. 55: 366 (1966).

3. Callahan, J. W., and Khalil, M.: Sphingomyelinases in human tissues. III. Expression of Niemann-Pick disease in cultured fibroblasts: Pediat. Res.. 9. 914 (1975).

4. Callahan, J. W., and Khalil, M.: Unpublished observations.

5. Callahan, J. W., Khalil, M., and Gerrie, J.: Isoenzymes of sphingomyelinase and the genetic defect in Niemann-Pick disease, type C. Biochem. Biophys. Res. Commun., 58: 384, (1974)

6. Callahan, J. W.. Khalil. M.. and Lowden, J. A.: Niemann-Pick disease, type C Absence of a sphingomvelinase isoenzume. Pediat. Res.. 8: I13 (1974).

7. Fredrickson, D. S., and Sloan, H. R.: Sphingomyelin lipidoses: Niemann-Pick disease. In: J. B. Stanbury, J. B. Wyngaarden, and D. S. Fredrickson: The Metabolic Basis of Inherited Disease, Chapt. 35, p. 783 (McGraw-Hill Book Co. New York, 1972).

8. Kamoshita, S., Aron, A. M., Suzuki, K., and Suzuki, K.: Infantile Niemann-Pick disease: A chemical study with isolation and characterization of membranous cytoplasmic bodies and myelin. Amer. J. Dis. Child., 117: 379 (1969).

9 Kanfer, J N. Young, D. M. Shapiro, D., and Brady, R. O. Metabolism of sphingomyelin: Purification and properties of a sphingomyelin cleaving enzyme from rat liver tissue. J. Biol. Chem., 24l: 1081 (1966).

10. Lowden, J. A., and La Ramee. M. A.: Sphingomyelinases in Niemann-Pick disease. Proc Amer. Soc. Neurochem.. I: 55 (1970).

11. Lowden, J. A., and La Ramee, M. A.: Personal communication.

12. Lowry, O. H., Rosebrough, N. J., Farr, A. L., and Randall, R. J.: Protein measurement with the Folin phenol reagent. J. Biol. Chem.. 193: 265 (1951).

13. Martin I I Philippart, M van Hauwaert, J Callahan, J. W and Deberdt. R. Niemann-Pick disease (Crocker's group A): Late onset and pigmentary degeneration resembling Hallervorden-Spatz syndrome. Arch. Neurol., 27: 45 (1972).

14. Norman, R, M Forrester, R, M and Tingey, A. H. The juvenile form of Niemann-Pick disease Arch. Dis. Childhood, 42: 91 (1967).

15. Novikoff, A. B.: Lysosomes: A personal account. In: H. G. Hers and F. van Hoof: Lysosomes and Storage Diseases, Chapt. 1, p. I (Academic Press, New York, 1973).

16. Philippart, M.: Glycolipid, mucopolysaccharide and carbohydrate distribution in tissues, plasma and urine from glycolipidoses and other disorders. In: V. Zambotti, G. Tettamanti, and M. Arrigoni: Glycolipids, Glycoproteins and Mucopolysaccharides of the Nervous System.p. 231 (Plenum Press. New York, 1972)

17. Philippart, M., Martin, L., Martin, J. J., and Menkes, J. H.: Niemann-Pick disease: Morphologic and biochemical studies in the visceral form with late central nervous system involvement (Crocker's group C). Arch. Neurol., 20: 227 (1969).

18. Rouser, G., Kritchevsky, G., Yamamoto, A.. Knudson. A. G., and Simon, G.: Accumulation of a glycerolphospholipid in classical Niemann-Pick disease. Lipids, 3: 287 (1968).

19. Sandhoff, K.. Harzer, K.. Wassle, W., and Jatzkewitz, H.: Enzyme alteration and lipid storage in three variants of TaySachs disease. J. Neurochem., 18. 2469, (1971).

20. Schneider, P. B., and Kennedy, E. P.: Sphingomyelinase in normal human spleens and in spleens from subjects with Niemann-Pick disease. J. Lipid Res. 8: $202(1967)$

21. Sloan, H. R., Uhlendorf, B. W., Kanfer, J. N., Brady, R. O., and Fredrickson, D. S.: Deficiency of sphingomvelin-cleaving enzyme activity in tissue cultures derived from patients with Niemann-Pick disease. Biochem. Biophys. Res. Commun., 34: 582 (1969).

22. Weinreb, N. J., Brady, R. O., and Tappel, A. L.: The lysosomal localization of sphingolipid hydrolases. Biochim. Biophys. Acta, 159: 141 (1968).

23. Wherrett, J. R., and Huterer, S.: Enrichment of bis-(monoacylglyceryl)-phosphate in lysosomes from rat liver. J. Biol. Chem., 247: 4114 (1972).

24. St. Louis, Mo.

25. Pittshurgh, Pa.

26. Bromma, Sweden

27. LKB Products, Bromma, Sweden.

28. The authors are indebted to Drs. Peggy J. Copple and J. Colin Buchan for the clinical data and autopsy material from case 1 .

29. Dr. J. W. Callahan is a Medical Research Council of Canada scholar.

30. This research was supported by Grant MA-4873 from the Medical Research Council of Canada.

31. Requests for reprints should be addressed to: J. W. Callaham, Ph.D., Research Institute, Hospital for Sick Children. 555 University Ave... Toronto. Ontario M5G 1 X8 (Canada).

32. Accepted for publication July 25,1975 